\title{
Communication
}

[Comunicação]

\section{Production and purification of beta-toxin from Clostridium perfringens type C}

[Produção e purificação da toxina beta de Clostridium perfringens tipo C]

\author{
A.V.A. Carvalho ${ }^{1}$, L.G.D. Heneine ${ }^{2}$, R.A. Assis ${ }^{1}$, V.L.V. Abreu ${ }^{1}$, L.A. Gonçalves ${ }^{1}$, F.C.F. Lobato $^{1 *}$ \\ ${ }^{1}$ Escola de Veterinária - UFMG \\ Caixa Postal 567 \\ 30123-970 - Belo Horizonte, MG \\ ${ }^{2}$ Fundação Ezequiel Dias - Belo Horizonte, MG
}

\begin{abstract}
Clostridium perfringens type $\mathrm{C}$ beta-toxin is involved in necrotic enteritis in humans and other animals. Despite having a worldwide distribution, so far, cases of that disease have not been reported in Brazil. Its diagnosis is most commonly obtained through the serum neutralization test in mice, which requires long periods of observation and large numbers of animals (El Idrisi and Ward, 1992). Regarding the in vitro tests for the detection of Clostridium perfringens type $\mathrm{C}$ beta toxin, ELISA is highly used because its sensitiveness, easiness to perform and reproductibility (Uzal et al., 1977). To develop an ELISA to detect beta-toxin specific antibodies is imperative. The production of specific anti-beta-toxin antibodies is desirable in order to obtain a highly purified toxin.
\end{abstract}

The present report describes the production, concentration and purification of beta-toxin produced by Clostridium. perfringens type $\mathrm{C}$ in order to obtain the development of an ELISA for the veterinary diagnose of necrotic enteritis.

The beta-toxin was produced from a strain of Clostridium perfringens type $\mathrm{C}$, donated by the Instituto Nacional de Tecnologia Agropecuária (INTA/Bariloche/Argentina).The microorganism was cultured into thioglycolate medium $^{1}$, in anaerobic conditions, at $37^{\circ} \mathrm{C}$. After $24 \mathrm{~h}$ of culture growth, $10 \mathrm{ml}$ of the culture was transferred to $500 \mathrm{ml}$ of medium for toxin production, as previously described by Lobato et al. (2000), and incubated at $37^{\circ} \mathrm{C}$, for $8 \mathrm{~h}$, in anaerobic conditions. The culture medium was centrifuged at $10.000 \times \mathrm{g}$, at $4^{\circ} \mathrm{C}$, for $30 \mathrm{~min}$. The supernatant was concentrated 10 times with a $10 \mathrm{kDa}$ cut-off membrane ${ }^{2}$. The retentate contained the beta-toxin.

Two different methods were employed for the purification of the beta-toxin. The culture medium was concentrated by ammonium sulphate precipitation and purified by metal affinity chromatography, using zinc as the chelating agent, according to Sakurai and Fujii (1987). For the immuno-affinity chromatography, the culture medium was filtered through a column containing protein $\mathrm{G}$ sepharose 4- ${ }^{3}$ to which sheep anti-toxin antibodies were covalently linked. Sheep were immunized with a beta-toxoid obtained following the method described by Heneine and Heneine (1998). The culture medium was applied to the column in equilibrium buffer and, after washing the column with two column volumes, in the same buffer, the toxin was eluted in the first peak with the eluting buffer (glycine+HCl $0.1 \mathrm{M} \mathrm{pH} 2.5$ ). The

\footnotetext{
${ }^{1}$ Dignolab, Barcelona, Spain

${ }^{2}$ Amicon, Beverly, USA

${ }^{3}$ Sigma, St. Louis, USA
}

Recebido em 3 de novembro de 2004

Aceito em 2 de agosto de 2005

*Corresponding author (autor para correspondência)

E-mail: flobato@vet.ufmg.br 
fractions were collected in tubes containing $1 \%$ $\mathrm{v} / \mathrm{v}$ Tris- $\mathrm{HCl} 1.0 \mathrm{M} \mathrm{pH} 8.0$ to bring the $\mathrm{pH}$ to a neutral value. The fractions comprising the first peak from both methods were subjected to sodium dodecyl sulphate, polyacrylamide gel electrophoresis (SDS-PAGE) and were silver stained. The SDS-PAGE for both methods showed a band of $38 \mathrm{kDa}$ for the beta-toxin, which is in accordance with previous reports (Sakurai and Duncan, 1978, Sakurai and Fujii, 1987, Hunter et al., 1993) and bands having higher molecular weights (Fig. 1).

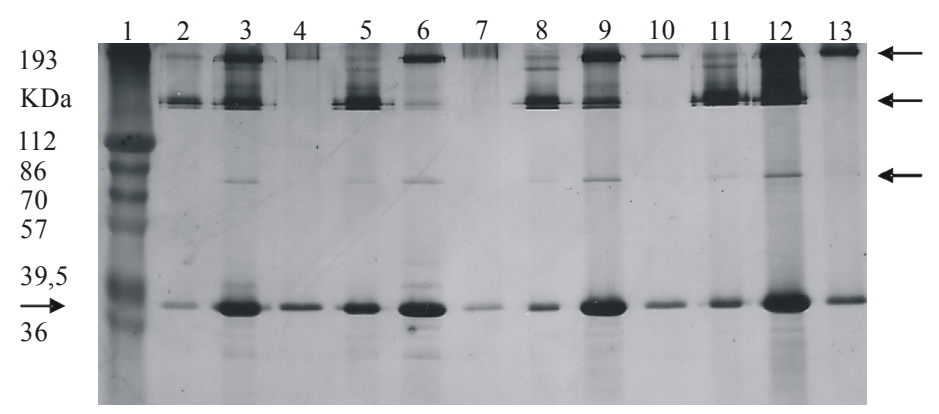

Figure. 1. Repeatibility of the purification of $\beta$ toxin by affinity chromatography. It is shown the silver stained fractions obtained in different chromatographyc runs (lanes 2 to 13). Arrows indicate bands of $36.453 \mathrm{kDa}$, a monomeric form of the toxin, and higher molecular weight bands the oligomeric forms. Lane 1-molecular weight marker.

The beta-toxin is produced as a monomeric form, but it is oligomerized (Hunter et al., 1993). The western blot analysis indicated that higher molecular weight bands are oligomers due to its reactivity to the anti beta-toxin antibodies.

The purification by the metal affinity chromatography resulted in relatively high purified beta-toxin form, but with low yielding. However, the immunoaffinity chromatography showed to be fast, yielding to larger amounts of purified toxin per run, in relation to the other method.

The production and purification of Clostridium perfringens type $\mathrm{C}$ beta-toxin will contribute to the development and validation of an ELISA to diagnose diseases caused by this toxin.

Keywords: Clostridium perfringens, beta-toxin, purification, metal affinity, immunoaffinity

\section{RESUMO}

Empregaram-se os métodos cromatográficos de afinidade metálica e de imunoafinidade para purificação da toxina beta em sobrenadante de cultivo de Clostridium perfringens tipo C. Observaram-se, na eletroforese das primeiras frações eluidas nos dois métodos de purificação, uma banda de peso molecular aproximado de $38 \mathrm{kDa}$, característica da forma monomérica de toxina beta de Clostridium perfringens tipo $C$, e bandas de peso moleculares superiores, referentes às suas formas oligoméricas. Maior rendimento foi obtido com a utilização do método de imunoafinidade.

Palavras-chave: Clostridium perfringens, toxin beta, purificaçcão, afinidade metálica, imunoafinidade 


\section{REFERENCES}

EL IDRISI, A.H.; WARD, G.E. Development of double sandwich ELISA for Clostridium perfringeus beta e epsilon toxins. Vet. Microbiol., v.31, p.89-99, 1992.

HENEINE, I.F.; HENEINE, L.G. Stepwise iodation. A general procedure for detoxification of proteins suitable for vaccine development and antiserum production (Review). Biologicals, v.26, p.25-32, 1998.

HUNTER, S.E.C.; BROWN, E.; OYSTON, P.C.F. et al. Molecular genetic analysis of betatoxin of Clostridium perfringens reveals sequence homology with alpha-toxin, gammatoxin, and leukocidin of Staphylococcus aureaus. Infec. Immun., v.61, p.3958-3965, 1993.
LOBATO, F.C.F.; MORO, E.; UMEHARA, O. et al. Avaliação da resposta de antitoxinas beta e epsilon de Clostridium perfringens induzidas em bovinos e coelhos por seis vacinas comerciais no Brasil. Arq. Bras. Med. Vet. Zootec., v.52, p.313318, 2000.

SAKURAI, J.; DUNCAN C. L. Some properties of beta toxin produced by Clostridium perfringens type C. Infec. Immun., v.21, p.678680, 1978.

SAKURAI, J.; FUJII, Y. Purification and Characterization of Clostridium perfringens beta toxin. Toxicon, v.25, p.1301-1310, 1987.

UZAL, F.A.; NIELSEN, K.; KELLY, W.R. Detection of Clostridium perfringens type D epsilon antitoxin in serum of goats by competitive and indirect ELISA. Vet. Microbiol., v.51, p.223-231, 1997. 